Article

\title{
Students' Perceptions and Experiences of Online Education in Pakistani Universities and Higher Education Institutes during COVID-19
}

\author{
Saad Arslan Iqbal ${ }^{1}$ (D), Murtaza Ashiq 2,3®D, Shafiq Ur Rehman ${ }^{3}{ }^{(0)}$, Shaista Rashid ${ }^{4, *}$ and Namra Tayyab 5 \\ 1 Department of Educational Policy Studies, Faculty of Education, University of Alberta, \\ Edmonton, AB T6G 2G5, Canada; saiqbal@ualberta.ca \\ 2 Department of Library and Information Science, Islamabad Model College for Boys, \\ Islamabad 44000, Pakistan; gmurtazaashiq00@gmail.com \\ 3 Institute of Information Management, University of the Punjab, Lahore 05422, Pakistan; shafiq.im@pu.edu.pk \\ 4 Department of Linguistics and Translation, College of Humanities and Sciences, Prince Sultan University, \\ Riyadh 11586, Saudi Arabia \\ 5 Independent Researcher, Dammam 34212, Saudi Arabia; ntayyab128@gmail.com \\ * Correspondence: srashid@psu.edu.sa
}

check for

updates

Citation: Iqbal, S.A.; Ashiq, M.;

Rehman, S.U.; Rashid, S.; Tayyab, N.

Students' Perceptions and

Experiences of Online Education in

Pakistani Universities and Higher

Education Institutes during

COVID-19. Educ. Sci. 2022, 12, 166.

https://doi.org/10.3390/

educsci12030166

Academic Editor: Neil Gordon

Received: 15 December 2021

Accepted: 22 February 2022

Published: 28 February 2022

Publisher's Note: MDPI stays neutral with regard to jurisdictional claims in published maps and institutional affiliations.

Copyright: () 2022 by the authors Licensee MDPI, Basel, Switzerland. This article is an open access article distributed under the terms and conditions of the Creative Commons Attribution (CC BY) license (https:/ / creativecommons.org/licenses/by/ $4.0 /)$.

\begin{abstract}
This study investigates the perceptions and experiences of students regarding the various aspects of online education while studying at the Pakistani Higher Education Institutes (HEIs) and universities that shifted to online modes of instruction during the COVID-19 pandemic. The focus of this study was to identify the level of satisfaction of students with the support being provided to them by their institutes and instructors; the use of different modes of communication and assessment methods; and their home study environment. It also explored the positively and negatively influencing factors affecting online education, as perceived by them. An online questionnaire-based cross-sectional survey research design was chosen for conducting this study. Data were collected from 707 respondents belonging to various Pakistani HEIs and universities and analyzed using the SPSS software. The results revealed a considerable dissatisfaction among the study population regarding online education being provided to them during the COVID pandemic. The participants raised concerns over the lack of institutional support and the quality of online instruction. Other issues raised included unsuitable study environments, unavailability of electricity, and connectivity issues. Overall, the majority of the students indicated that they would not like to opt for online classes in the future once the pandemic was over.
\end{abstract}

Keywords: online education; e-learning; distance learning; online education barriers; emergency remote teaching; online education-developing countries; COVID-19

\section{Introduction}

Since the emergence of the COVID-19 pandemic, governments around the world have had to take extreme measures to curb its spread. These measures have included limiting the movement of individuals, instigating city-wide lockdowns [1], and closing schools and universities. The closure of educational institutes has prompted a transition from the traditional face-to-face learning methods to online or distance learning modes to ensure the continued delivery of learning [2-4]. This sudden transition from traditional to online education has affected students in many ways. According to the International Association of Universities [5], the school and university closures have impacted more than 1.5 billion students and youth globally. UNESCO estimates that as many as $60 \%$ of the global student population has been affected due to nationwide closures of educational institutions [6]. The adoption of online modes of education has been particularly challenging for developing countries such as Pakistan where financial constraints and accessibility and connectivity 
issues hinder the transition to online learning [7]. Only those already familiar with elearning, blended learning, and ICT tools have found this shift manageable [3,8,9]. However, despite the inherent difficulties, the COVID-19 pandemic has allowed educators and students to explore more flexible learning possibilities with blended methods such as mixing synchronous and asynchronous methods [2]. Furthermore, the lessons learned from this transitional process would make institutes around the world more resilient and better equipped to deal with such crises in the future $[2,10]$. Given the emergent nature of this transition, careful consideration must be given to assessing the quality of online education provided during the pandemic. It has been implemented without any proper planning and deliberation and may have some shortcomings. Many researchers have used the term "emergency remote teaching" $[4,8,11,12]$ when referring to the education being provided during the pandemic.

Previously, several studies have analyzed the different aspects of e-learning and online education [13-21]. However, most of them have examined online education in instances where it was being offered as a planned modality and not as a response to an emergency. It is important, therefore, to note that in the context of this study online education is referring to the education provided as an emergency response during the pandemic. There is a need to research and formally document the experiences and challenges being faced by teachers and students while engaged in online teaching and learning during the COVID 19 pandemic. This would help identify learning and teaching strategies best suited to the online academic environment keeping in mind the socio-cultural norms of the users [22].

Most of the literature in this area has emerged from the USA, Europe, or other developed countries. With the few exceptions from China, it is important to note that the social and cultural factors vary greatly between developed and developing countries. Similarly, the ICT infrastructure, which is the backbone of online teaching, is not comparable between developed and developing countries. For a better understanding and generalizability of research in this area, further investigations focusing on developing economies are required. Numerous studies have offered insights into online education during the pandemic in Pakistan [7,23-28]. However, many of them have either focused on specific disciplines or are based on a limited number of institutions. This study aims to fill the gap in the literature. To the best of our understanding, this study is the first of its kind to provide a comprehensive perspective of students' experiences regarding online education spanning various types of universities and academic disciplines.

It is hoped that, although exploratory in nature, this study would provide valuable information to the decision-makers in developing countries and allow them to develop appropriate guidelines and procedures needed to address unexpected situations such as the COVID 19 pandemic in the future. To explore students' perceptions and experiences of online education, the objectives of the study were (a) to identify the effects of organizational/institutional support, instructors' role, and the home study environment in online learning, (b) to explore the positive and negative influential factors perceived by students while learning online, and (c) to foresee students' preferences for taking online classes in the future.

Pakistan recorded its first two cases of COVID-19 on 26 February 2020, [29-31]. As a result of a continued increase in the number of new cases, the educational institutes across Pakistan were initially closed between 13 March 2020 and 5 April 2020 [32,33], however, this closure was later extended until 31 May 2020 [33,34]. The Higher Education Commission of Pakistan (HEC), whose role is to provide funding and oversee the regulation and accreditation of the higher education institutions in Pakistan, gave instructions to universities across the country to prepare for the online mode of teaching [35,36]. The HEC allowed the institutes whose Learning Management Systems (LMS) were well in place to offer online teaching while those institutions which were not ready to shift to the online mode were advised to ensure their 'online readiness' before offering online classes to their students [37,38]. Even after more than a year has passed since the emergence of COVID-19 pandemic, university closures are still enforced in specific regions and cities in Pakistan. 
Most of the decisions and implementations made by the universities and HEIs in the country were abrupt and, on occasion, prematurely planned. Consequently, there is a need to analyze the impact of this sudden transition in the teaching and learning modalities on students' perceptions, and to identify areas that need improvement. This may help the universities and HEIs in Pakistan to 'prioritize' their efforts according to their significance and to enhance their students' learning experience and performance in online formats in the future, especially during similar crises. This study is also significant given the fact that no such effort has been made until now to analyze the provision of online education and students' satisfaction, also comparing the various academic disciplines being offered in Pakistani universities and HEIs.

\section{Online and Distance Education in Pakistan}

In Pakistan, most of the higher education institutes use traditional or face-to-face modes of education, and online education is not as widely used. However, a few institutes have been using other methods such as distance learning and virtual learning. Two institutes stand out in this category. The first is Allama Iqbal Open University, which was established in 1974 with an aim to utilize information technology in providing education to the masses, especially the working class and those living in remote areas of the country [39]. Another one is the Virtual University of Pakistan, which was established in 2002 whose aim is to provide affordable education to students around the country using modern information and communication technologies [40]. Since these institutes had pre-established systems of teaching and learning online, they did not face significant challenges in continuing their educational activities during the pandemic [35].

On the other hand, many educational institutes were not able to offer online education to their students at the advent of the COVID 19 pandemic, owing to a lack of a reliable management structure for adopting online education and general unpreparedness for such situations [2]. Notably, the lack of preparedness for online mode of instruction has been a bigger issue for developing countries [41] as compared to the others. Due to a rapid shift from traditional to online teaching modalities, students across Pakistan, especially those living in remote areas, have faced widespread internet access and connectivity problems [33,35,37,42-44]. Students have also reported attention and concentration issues while online sessions are in progress [23]. Students have also raised concerns related to the quality of instruction, digital readiness (lack of training) of instructors, technical issues, and the quality of online evaluations [37]. Mukhtar, Javed, Arooj, and Sethi [23] have also highlighted the importance of quality enhancement of teaching and assessments. Another issue raised by Farooq, Rathore, and Mansoor [22] is that the quality of online education might not be standardized across institutions, which calls for a collaborative approach to overcoming these challenges.

Since online education has not been a widespread mode of instruction in many Pakistani universities before the emergence of COVID-19, it is understandable that many educational institutes have found it difficult to address the challenges that arose due to the pandemic. While previously, online education has been used to provide an alternative to allow students to continue their learning, the focus on the effectiveness of online education has been limited. However, since subsequent waves of the pandemic are still making face-to-face engagements between students and instructors difficult, it is warranted that the educational institutes offering online education should come up with solutions that best respond to the needs of their students and instructors to ensure an effective conduct of teaching and learning activities. The issues of quality of instruction and modes of communication, the use of online assessment methods, internet, and connectivity problems are significantly affecting the students. It is, therefore, important to understand how the students reflect on their experiences of online education. Through a better understanding of students' experiences, the educational institutions can make timely and effective decisions in order to improve their teaching and learning processes. 


\section{Review of Literature}

Online learning encompasses the use of the internet, intranet, or extranet along with animations, simulations, audio, video sequences, discussion groups, online mentoring, online feedback, online sharing of learning and resource materials. Mayes, Luebeck, $\mathrm{Ku}$, Akarasriworn, and Korkmaz [15] have identified "two-way audio and video communication, electronic whiteboards, interactive formative assessment tools, Java-based applets, blogs and wikis, and shared access to software" as the major resources used in an online environment.

Online education is not a new phenomenon in the international educational landscape and has long been explored around the world in various forms and magnitudes. Over the years, the use of online and distance education has grown exponentially and become very popular [18]. It has been argued that online education has made its mark and would persist as a relevant way of education in the future due to the various benefits it offers $[14,45]$. However, online or distance education in the current scenario, where it might be referred to as 'emergency online education' [2], is relatively new and one whose implications are constantly unwrapping in front of the international community.

\subsection{Factors That Facilitate Students' Learning Experiences in Online Environments}

\subsubsection{Organizational Support in Facilitating Online Learning Environments}

Institutional facilitation of the students and instructors is an important aspect of online education that can affect the quality of online education. It has been posited that organizational policies significantly contribute towards instructors' satisfaction [46], and organizational decisions can impact the quality of instruction [47]. In addition, active communication from university officials in times of crisis helps the students and faculty to stay informed, motivated, and positive throughout the process $[8,48]$. Literature has also suggested that instructors in online settings relied on institutional support and resources in offering student-centered learning environments $[47,49]$. From the instructors' perspective, factors such as collaboration, training, and support from the institution have been considered critical for effective teaching [47]. However, it should be noted that the training provided to the instructors may sometimes be incongruous to the needs of the educators or be simply not fit for purpose [50]. The collective outcome of all these issues might directly or indirectly affect the students' satisfaction with the online teaching and learning processes. The importance of institutional role becomes even more crucial in times of crises, and the COVID-19 pandemic has recently highlighted this. Rajab et al. [51] have recently indicated that faculty members surveyed by them appreciated the help given to them by their institute in making resources and real-time support services available.

As far as students are concerned, research indicates that if the learners were well versed with the use of educational technologies and tools, their level of satisfaction with an online course would be higher than those who were not [52]. However, even self-reported technologically savvy students might require technical support at times [49]. Students have identified factors such as ease of use, user-friendliness, security, speed, and responsiveness as having an impact on their online learning environment and experience [53]. The recent pandemic has also revealed the need for systemic support and guidance during such times [10]. It has been reported that students required a clearer indication and implementation of ICT policies while studying online [54]. Lack of equity and support devices were key issues that required consideration at the institutional level $[55,56]$. The University of West Indies has been applauded in literature for the timely provision of short-term loans and internet access to the students and staff during the transition [8]. However, it has been noted that institutes in developing countries might not be able to achieve the same levels of preparedness, response, recovery, and mitigation strategies as their developed counterparts [41]. 


\subsubsection{Instructors' Role in Facilitating Online Learning Environments}

There is a strong connection between instructors' actions and students' satisfaction in an online course [21]. Brocato et al. [20] reported that even though students' perceptions regarding traditional and online classroom settings might differ, they were primarily interested in gaining 'mastery' of the course through meaningful learning experiences. Estelami [57] indicated that student satisfaction was directly affected by the course content, student-teacher communications, use of effective learning tools, and instructor's way of presentation. Timely and constructive feedback on course activities was also considered helpful by students in studying in online environments $[15,58,59]$. Furthermore, instructors' accessibility and timeliness of their responses could significantly improve students' positive perception of the value of online courses [21]. Adnan and Anwar have reported that during the COVID 19 pandemic, students have indicated that face-to-face contact with instructors was very important for their effective learning but was considered difficult during distance learning [7]. Recently, many researchers [51,60,61] have reiterated the importance of quick and concise feedback when making the transition to remote modes during the COVID-19 pandemic.

\subsubsection{Modes of Communication and Assessment Methods Used in Online Education}

Instructors can use a variety of communication modes in an online setting based on different factors. These tools could be synchronous or asynchronous [62]. In a wellstructured course with effective course content and an appropriate communication plan, online courses could be as effective as face-to-face courses [19]. It has been suggested that dividing the students' learning experiences into an offline self-learning phase and an online teaching phase could enhance their overall learning experience [60]. Abramenka [62] reported that students preferred using e-mail and other asynchronous communication tools for interaction between them and their instructors. Although educational institutes and instructors were largely unprepared for the massive shift from traditional to online modes of teaching, instructors/institutes tried to use different modes of communication and assessment methods to facilitate students' learning experiences $[8,63,64]$.

Literature originating during the pandemic suggests that the sudden shift from a traditional to an online mode of education has significantly impacted the student assessment and evaluation processes [48]. Students were more likely to find online examinations difficult as compared to traditional examinations [26]. Under such circumstances, instructors and institutions need to implement safe, reliable, valid, and fair methods of assessment [65]. However, this could be a challenging endeavor due to the multifaceted implications of the pandemic.

\subsubsection{Students' Study Environment and Resource Readiness for Online Learning}

Student satisfaction with online systems could depend upon their personal attributes, environmental pressures, and e-learning facilities available to them [50]. Callo and Yazon [66] have noted that factors such as learner familiarity, capability, preparation, device and access connectivity, self-efficacy and experience with technology influenced learners' readiness and conduct during online teaching and learning. Likewise, the participants of a study by Paudel [54] mentioned that computer literacy, technological preparedness, and time management skills were important for online learning.

Students' home-study environment or other demographic aspects might also have significant positive or negative influences on their study processes and experiences. Aristovnik et al. [67] recently conducted a study and concluded that students possessing certain demographic characteristics tended to show significantly less satisfaction levels regarding their academic work/life during the COVID 19 crisis. Furthermore, those belonging to Africa, Asia, and South America reported the lowest availability of a quiet place to study. Other factors like unstable network speed, noisy environment, and lack of professional equipment [68] and familiar learning space [69] might also hinder the students' learning experiences during the ongoing emergency remote education. Similarly, disparities in access 
and use of online learning between students living in rural and those living in urban areas have also been reported to impact the level of student satisfaction in the two areas [70].

\subsection{Positively Influential Factors and Motivators in Online Education}

Factors such as intrinsic motivation, maturity, good time management, and active participation in class activities have been deemed crucial for determining a student's success during online learning [47]. Students tended to view flexibility and convenience in online education as an advantage [14,53,71,72], and also considered online education beneficial for them since it allowed them to take additional job opportunities or continue existing ones [73]. Other benefits of positively influential factors included cost-effectiveness and time saving [73,74] aspect of online learning and a reduction in transportation costs [52], motivation to use technology [75], as well as the ability to have self-directed [58] and self-centered learning [23]. Although online education during crises situations received less satisfaction among students, a recent study by Rafique, et al. [76], surveying LIS students in Pakistan, found that the students were not only receptive to new ideas but also motivated to learn online, and were willing to interact and engage with fellow students.

\subsection{Negatively Influential Factors and Demotivators in Online Education}

One of the biggest challenges in online education, especially in the context of an underdeveloped country, has been identified as the unavailability of electricity [52]. Furthermore, the presence of weak satellite connections [77] and poor or no internet access [47,78] may hinder student performance in online education. Difficulty in collaborating with fellow learners could also affect students' satisfaction and academic performance in online environments [62]. Lack of clarity in course design and layout could also contribute to students confusion [62]. The utilization of social media platforms for learning could also lead to distracted students if quality content is not created [79]. Researchers have noted that online programs are not always successful in arousing interest among students [78] and that it was easy for students to lose focus in online environments $[56,61]$. Online learning can also engender a feeling of isolation among students [15,52,58,62,80,81] and also encourage procrastination $[62,72,80]$.

Recent studies have pointed out that distraction, workload, and technological problems [82], connectivity issues [71], and anxiety due to the uncertainty of the situation [51] were some of the major challenges inherent in online learning. The effects of social distancing, isolation, and uncertainties related to the pandemic may also impact the mental health of students and staff [79].

According to the available literature, students' online learning experiences are greatly influenced by various factors such as the organization's support provided during online education, the instructors' role such as methods of instruction, modes of communication, and assessment methods, as well as their home study environment and resource readiness. Certain factors such as flexibility, convenience, and motivation to use technology can contribute positively while factors such as internet and connectivity issues, lack of concentration and isolation may affect the students' experiences negatively.

\section{Research Questions}

To investigate the factors that influence students' learning and their experiences during online education, this study is based on the following research questions:

RQ1. To what extent were the students satisfied with the organization's support, the instructors' role, and the home study environment for facilitating online education?

RQ2. What were the positive and negative influential factors affecting students' online learning experiences?

RQ3. To what extent did the students prefer taking online classes in the future?

RQ4. Is there any significant difference of opinion based on gender, institution, and academic discipline? 


\section{Methodology}

The study aimed to explore the experiences of students engaged in online education while studying in higher education institutes in Pakistan during the COVID 19 pandemic. A questionnaire-based cross-sectional survey design was chosen for the study. Due to the non-availability of a relevant instrument, a comprehensive instrument was developed after reviewing the relevant literature, with a special focus on the various aspects of online education such as university and instructor support, preferred modes of communication, preferred assessment strategies, and the motivators and demotivators for students while studying online. The questionnaire was then reviewed by three experts in the field and modified per their feedback. The reliability of the instrument was established through Cronbach's alpha (0.92). The final instrument consisted of 45 items that measured the provision of online education in five aspects: (1) organizational support during online education, (2) instructors' role in facilitating online education, (3) study environment and resource readiness, (4) positive and negative influential factors for online learners, and (5) students' preference for taking online courses in the future (Appendix A).

The target population of the study comprised of Pakistani university students (undergraduate, graduate, and research students) studying in universities that had shifted to online teaching and learning modalities during the COVID-19 pandemic. The ethical approval for the study was granted by the Institute of Information Management, University of Punjab, Lahore. The online survey contained an information sheet to make sure informed consent was obtained prior to the collection of data. The sampling was done in two stages. In the first stage, a list of 157 Pakistani universities providing online education was identified through HEC data repository. Out of these 157 universities, we randomly selected 45 universities which are offering programs in multiple disciplines such as social sciences, sciences, engineering and technology, arts and humanities, business, etc. In the second stage, since the researchers did not have access to a complete list of students studying in the selected 45 universities, the researchers contacted various departments of these universities to collect data through the convenience sampling method. The data collection was achieved via a web-based questionnaire developed on QuestionPro. Once created, the questionnaire link was shared with the students through WhatsApp and Facebook groups. Additional help was sought from the various university faculty groups and heads of departments in disseminating the questionnaire link among their students. A total of 707 responses were received consisting of 441 female and 266 male students. The data analysis was performed using SPSS software (version 22).

\section{Results}

\subsection{Personal and Academic Profile of Participants}

Table 1 summarizes the demographic information of the participants. Among 707 participants, $441(62 \%)$ were female and $266(38 \%)$ were male. The majority of the participants $(589,83 \%)$ belonged to public sector universities. The largest group of the participants were enrolled at the Undergraduate level (436, 62\%), followed by the Graduate $(200,28 \%)$, and Postgraduate levels $(71,10 \%)$. The major academic disciplines of the participants were Social Science (173, 24\%), then, Sciences (131, 19\%), Engineering and Technology (116, 16\%), Business/Management/Commerce (101, 14\%), Arts and Humanities (78, 11\%), Agriculture $(63,9 \%)$, and Health Sciences $(45,6 \%)$. With regards to the arrangement of the study areas, of the 696 participants who answered, the majority of the students reported having a shared study room $(452,65 \%)$ while $244(35 \%)$ indicated having an independent room facility. A total of 684 participants answered for the various types of accommodation and the majority mentioned living in a 3 or above bed apartment/house $(275,40 \%)$, followed by $1-2$ bed apartment/house $(251,37 \%)$, public or private hostel $(101,15 \%)$, room on rent $(43,6 \%)$, and single bed/studio apartment $(14,2 \%)$. 
Table 1. Personal and academic profile of the participants.

\begin{tabular}{|c|c|c|}
\hline Variable & Frequency & Percentage \\
\hline \multicolumn{3}{|l|}{ Gender } \\
\hline Female & 441 & 62 \\
\hline Male & 266 & 38 \\
\hline Total & 707 & 100 \\
\hline \multicolumn{3}{|l|}{ Type of University } \\
\hline Public & 589 & 83 \\
\hline Private & 118 & 17 \\
\hline Total & 707 & 100 \\
\hline \multicolumn{3}{|l|}{ Level of Enrollment } \\
\hline Undergraduate (e.g., BA, BSc) & 436 & 62 \\
\hline Graduate (e.g., MA, M.Sc., BS Hons) & 200 & 28 \\
\hline Postgraduate (e.g., MPhil., PhD) & 71 & 10 \\
\hline Total & 707 & 100 \\
\hline \multicolumn{3}{|l|}{ Major Disciplines } \\
\hline Social Science & 173 & 25 \\
\hline Sciences & 131 & 19 \\
\hline Engineering and Technology & 116 & 16 \\
\hline Business/Management/Commerce & 101 & 14 \\
\hline Arts and Humanities & 78 & 11 \\
\hline Agriculture & 63 & 9 \\
\hline Health Sciences & 45 & 6 \\
\hline Total & 707 & 100 \\
\hline \multicolumn{3}{|l|}{ Arrangements for Study } \\
\hline Shared study room & 452 & 65 \\
\hline Independent study room & 244 & 35 \\
\hline Total & 696 & 100 \\
\hline \multicolumn{3}{|l|}{ Types of Accommodation } \\
\hline 3 or Above Bed Apartment/House & 275 & 39 \\
\hline 1-2 Bed Apartment/House & 251 & 36 \\
\hline Public or Private Hostel & 101 & 14 \\
\hline Room on rent & 43 & 6 \\
\hline Single Bed/Studio Apartment & 14 & 5 \\
\hline Total & 684 & 100 \\
\hline
\end{tabular}

\subsection{Factors Which Facilitate Students' Lerning in Online Environments}

\subsubsection{Organizational Support for Facilitating Online Education}

Table 2 shows the students' evaluation of the support and guidance provided by the institutes on the use of online learning management systems, learning resources, technical support, and the provision of complaints registry during online education. The overall mean score $(M=1.99)$ showed considerable dissatisfaction levels among the students. Three statements related to 'guidance/tutorials', 'guidelines/policies shifting from traditional to online mode' and 'availability of learning material and library resources' had mean scores of $\mathrm{M}=2.08,2.06$, and 2.04, respectively, which shows that they were 'slightly satisfied'. However, the students were less satisfied with the 'technical support' and 'provision for registering grievances or complaints' by the university.

\subsubsection{Instructors' Role in Facilitating Online Education}

Table 3 discusses the students' ratings of the instructors' role during the online education phase. With respect to the faculty members' role and support during online education, all 10 statements received below 3 mean scores. The overall mean score $(M=2.39)$ showed that the students are 'slightly satisfied'. The three major concerns for the students were 
'convenient exam schedules' $(\mathrm{M}=2.11)$, 'timely and continuous feedback on class progress' $(\mathrm{M}=2.17)$, and 'follow-up and motivation to improve class progress' (2.21).

Table 2. Organizational support for facilitating online education.

\begin{tabular}{ccc}
\hline Statements & Mean & SD \\
\hline $\begin{array}{c}\text { Guidance/tutorials on the access and use of learning management } \\
\text { systems or other modes of online education. }\end{array}$ & 2.08 & 1.035 \\
\hline $\begin{array}{c}\text { Clear guidelines/policies on shifting from traditional to the online } \\
\text { mode of education. }\end{array}$ & 2.06 & 1.042 \\
\hline $\begin{array}{c}\text { Availability of learning material and library resources for } \\
\text { course completion. }\end{array}$ & 2.04 & 1.062 \\
\hline Technical support to overcome any technical difficulties. & 1.90 & 0.994 \\
\hline Provision for registering any grievances or complaints. & 1.90 & 0.978 \\
\hline Overall & 1.99 & 0.838 \\
\hline
\end{tabular}

Scale: 1 = Not at all satisfied, 2 = slightly satisfied, 3 = moderately satisfied, 4 = very satisfied, 5 = extremely satisfied.

Table 3. Instructors' role in facilitating online education.

\begin{tabular}{ccc}
\hline Statements & Mean & SD \\
\hline Opportunities given to ask questions & 2.94 & 1.174 \\
\hline Flexibility in following assignment deadlines & 2.58 & 1.206 \\
\hline $\begin{array}{c}\text { Clear guidelines about assignments and assessments } \\
\text { Availability for consultation and guidance after class hours } \\
\text { (WhatsApp, Messages, E-mails, etc.) }\end{array}$ & 2.56 & 1.180 \\
\hline In-time delivery of course content & 2.52 & 1.213 \\
\hline Appropriate pace of lectures & 2.41 & 1.060 \\
\hline The overall quality of course content & 2.26 & 1.031 \\
\hline Follow-up and motivation to improve class progress & 2.24 & 1.022 \\
\hline Timely and continuous feedback on class progress & 2.21 & 1.143 \\
\hline Convenient exam schedules & 2.17 & 1.104 \\
\hline Overall & 2.11 & 1.122 \\
\hline
\end{tabular}

Scale: 1 = Not at all satisfied, 2 = slightly satisfied, $3=$ moderately satisfied, $4=$ very satisfied, $5=$ extremely satisfied.

\subsubsection{Modes of Communication Used during Online Education}

The respondents were asked to inform about the modes of communication used by the instructors during online education. The respondents could choose more than one option out of a total of six (see Figure 1). The majority of the students highlighted that the instructors frequently used 'online lecturers/videos' $(43 \%)$, followed by 'recorded lectures' and 'social media apps' (17\%), 'e-mail correspondence' $(12 \%)^{\prime}$ ', 'website links for reading material' $(7 \%)$, and 'course websites' $(4 \%)$.

\subsubsection{Types of Assessment Methods Used during Online Education}

The respondents were also asked to indicate the types of assessment used by instructors during the online education phase (see Figure 2). Amongst the seven assessment types, the majority of the respondents highlighted that the widely used assessment types were 'individual assessment' (25\%), followed by 'group discussions' (20\%), 'group assignments' $(15 \%)$, 'oral/written quizzes' (13\%), 'juries or presentations and one-to-one discussions $(9 \%)$, 'written examinations' ( $7 \%)$, and 'other' $(2 \%)$. Surprisingly, the 'written examination' was the least used assessment method at the time of the study. 


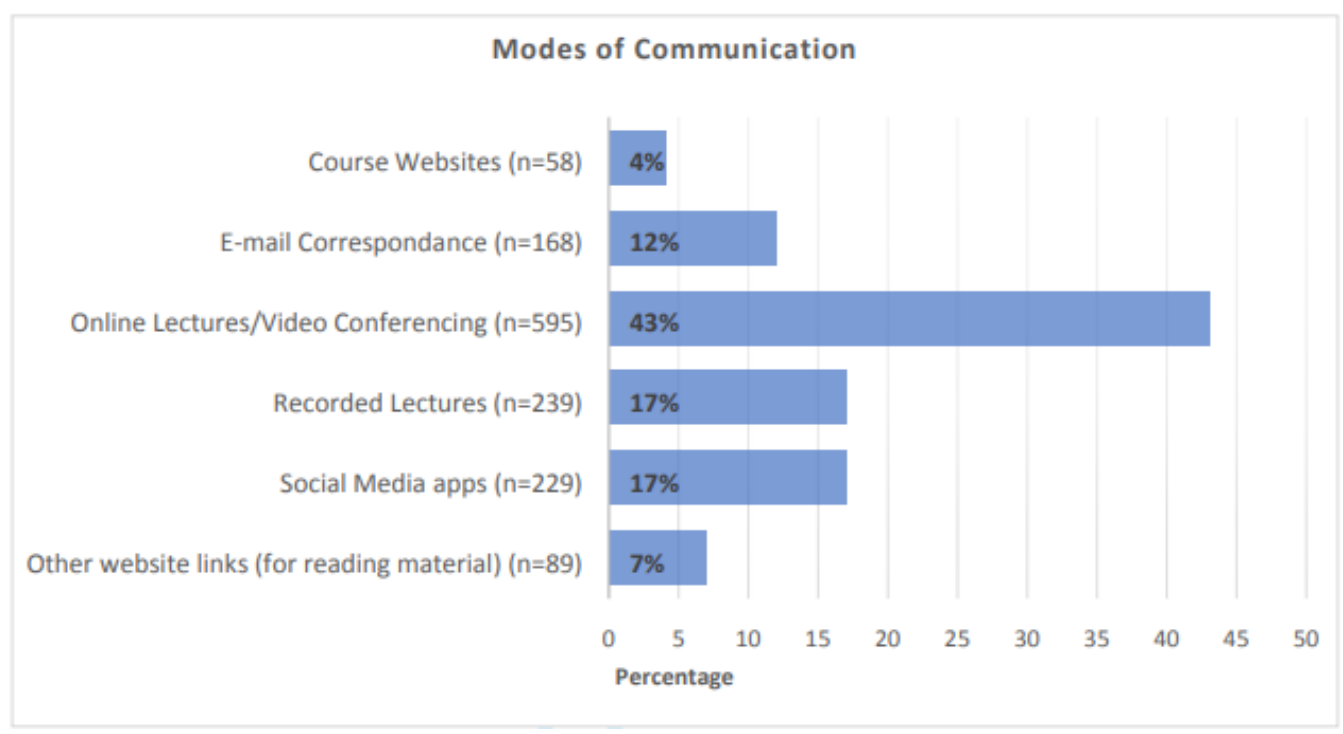

Figure 1. Modes of communication used by instructors for online teaching.

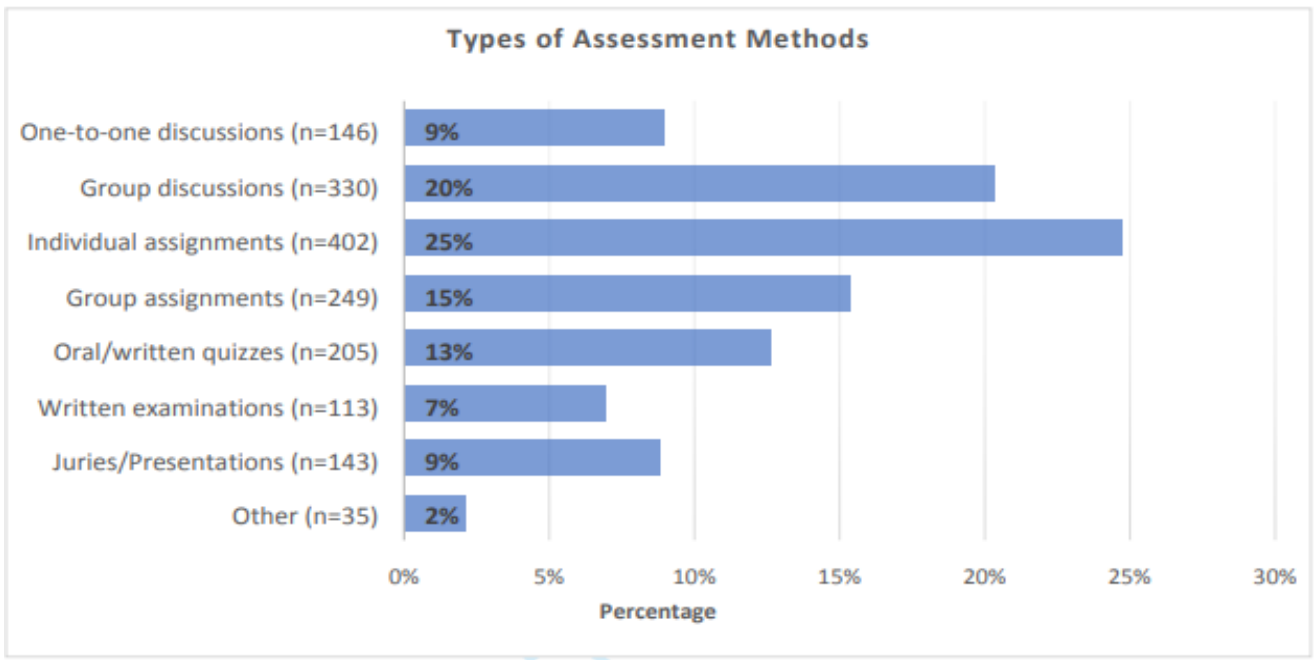

Figure 2. Types of assessment methods used by instructors for online teaching.

\subsubsection{Students' Study Environment and Resource Readiness during Online Learning}

Table 4 indicates the quality of the home study environment of the participants. The overall mean score $(\mathrm{M}=2.42)$ demonstrates that the condition of the home study environment during online learning was 'fair'. All of the statements received below 3 mean scores. The three statements with the lowest mean score were 'quality of outside/surrounding environment' $(\mathrm{M}=2.10)$, 'quality of internet connection' $(\mathrm{M}=2.26)$, and 'availability of electricity in the area' $(\mathrm{M}=2.43)$.

\subsection{Positively Influential Factors Associated with Online Learning}

Table 5 describes the quality of online teaching and learning as perceived by the students. The overall mean score of the statements $(\mathrm{M}=2.76)$ indicates students' disagreement with the provision of online teaching and learning. There are only two statements (out of 10) that had a mean score of more than 3, 'saving transportation costs' $(\mathrm{M}=3.23)$ and 'increasing skills in software and tools' $(\mathrm{M}=3.08)$. The respondents showed their disagreement with most of the statements (from lowest to highest mean score). The three major statements with disagreements were 'online learning to be more convenient and flexible' $(\mathrm{M}=2.09)$, 'maintaining motivation and enthusiasm while taking online classes' $(\mathrm{M}=2.39)$, and 'better time management skills' $(\mathrm{M}=2.64)$. 
Table 4. Students' study environment and resource readiness during online learning.

\begin{tabular}{ccc}
\hline Statements & Mean & SD \\
\hline $\begin{array}{c}\text { The availability of required devices and facilities (computer/tablet, } \\
\text { cellphone, printer, study table, etc.) }\end{array}$ & 2.76 & 1.192 \\
\hline $\begin{array}{c}\text { The level of in-house support and facilitation from } \\
\text { family/friends/roommates etc. to concentrate }\end{array}$ & 2.57 & 1.169 \\
\hline The availability of power supply (electricity) in your area & 2.43 & 1.081 \\
\hline The quality of internet connection & 2.26 & 1.095 \\
\hline The quality of outside/surrounding environment & 2.10 & 1.113 \\
\hline Overall & 2.42 & 0.848 \\
\hline
\end{tabular}

Scale: 1 = Poor, 2 = fair, 3 = good, 4 = very good, 5 = excellent.

Table 5. Factors which positively influence online learning.

\begin{tabular}{ccc}
\hline Statement & Mean & SD \\
\hline $\begin{array}{c}\text { I was able to cut down on transportation costs. } \\
\text { My command in using the relevant software and required tools } \\
\text { has increased. }\end{array}$ & 3.23 & 1.154 \\
\hline My ability to practice self-responsibility has increased. & 2.99 & 1.096 \\
\hline My ability to practice self-discipline has increased. & 2.92 & 1.092 \\
\hline $\begin{array}{c}\text { a was able to manage my time effectively (completing assignments, } \\
\text { assents, etc.) }\end{array}$ & 2.81 & 1.157 \\
\hline $\begin{array}{c}\text { I was quite successful in using the relevant software and } \\
\text { required tools. }\end{array}$ & 2.77 & 1.156 \\
\hline $\begin{array}{c}\text { I was able to focus on additional things (part-time job, hobbies etc.) } \\
\text { My time-management skills have increased. }\end{array}$ & 2.75 & 1.210 \\
\hline I was able to maintain motivation and enthusiasm while taking & 2.64 & 1.097 \\
\hline I found online learning to be more convenient and flexible & 2.39 & 1.097 \\
\hline$\quad$ Overall & 2.09 & 1.098 \\
\hline
\end{tabular}

Scale: 1 = strongly disagree, 2 = disagree, 3 = neutral, 4 = agree, 5 = strongly agree.

\subsection{Negatively Influential Factors Associated with Online Learning}

The respondents were asked to inform which factors were 'negatively influential' on their online learning from a list of 10 factors (see Table 6). The overall mean score ( $\mathrm{M}=3.31)$ showed that all factors were 'somewhat influential'. The top five major influential factors were 'disruption in sleeping pattern' $(M=2.90)$, 'inability to grasp concepts' $(M=3.07)$, 'lack of sense of place' $(\mathrm{M}=3.11)$, 'feeling overburdened with academic tasks' $(\mathrm{M}=3.29)$, and 'irregular routine (3.32).

\subsection{Preference of Online Classes after the COVID-19 Pandemic}

Additionally, the students were asked to inform about their willingness to take online classes in the future, after the COVID-19 pandemic was over (see Figure 3). Understandably, most of the respondents $(75 \%)$ indicated their dislike of online classes by choosing 'very unlikely' (58\%) and 'Unlikely' (17\%). A total of $15 \%$ remained 'neutral' and only $11 \%$ indicated that they were likely to take online classes after the COVID-19 pandemic, choosing 'likely' ( $8 \%)$ and 'very likely' (3\%). The results indicate that the majority of the students $(75 \%)$ did not like online classes and would prefer not to take them in the future. 
Table 6. Factors which negatively influence online learning.

\begin{tabular}{ccc}
\hline Statements & Mean & SD \\
\hline Lack of hands-on/practical training & 3.57 & 1.388 \\
\hline Lack of student-student interaction & 3.52 & 1.371 \\
\hline Lack of interpersonal and communication skills & 3.46 & 1.343 \\
\hline Lack of student-teacher interaction & 3.46 & 1.294 \\
\hline Online learning boredom/difficulty in concentrating & 3.38 & 1.295 \\
\hline Lack of sense of time/irregular routine & 3.32 & 1.272 \\
\hline Feeling overburdened with academic tasks and responsibilities & 3.29 & 1.334 \\
\hline Lack of sense of place & 3.11 & 1.245 \\
\hline Inability to grasp concepts, learning objectives effectively & 3.07 & 1.289 \\
\hline Disruption in sleeping pattern & 2.90 & 1.277 \\
\hline Overall & 3.31 & 0.96 \\
\hline
\end{tabular}

Scale: 1 = Not at all influential, 2 = slightly influential, 3 = somewhat influential, $4=$ very influential, $5=$ extremely influential.

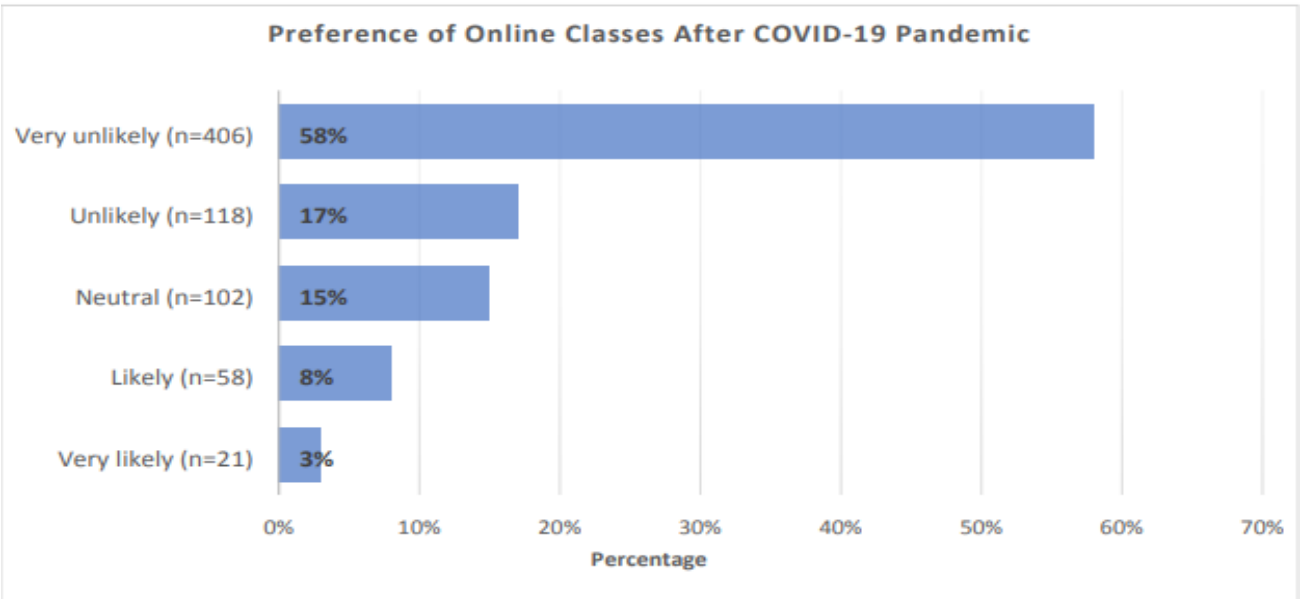

Figure 3. Preference of online classes after the COVID-19 Pandemic.

\subsection{Differences in Students' Opinions and Perceptions Based on Selected Variables \\ 5.6.1. Difference of Opinions Based on the Gender}

Table 7 shows the independent sample t-test results based on gender and university types. With respect to gender, there was only one significant difference of opinion found between male and female respondents (out of five variables) regarding 'preference of taking online classes in the future after the COVID-19 is over' $\leq 0.00$. The mean score of male respondents (mean $=2.00$ ) informed that they disliked online education more than the female respondents $($ mean $=1.71)$. Overall, the respondents were not willing to take online classes after the COVID-19 was over.

\subsubsection{Difference of Opinions Based on the Type of University/Institute}

A difference of opinion was observed on three variables based on the type of university (Table 8). The students had a difference of opinion regarding the 'University input/level of support' during online education, and 'positively influential factors', and 'instructors' role in providing online education'. However, they had similar opinions regarding the negatively influential factors based on the type of university.

The students from the private sector universities (mean $=2.22$ ) were slightly more satisfied than the public sector students (mean $=1.95)$ with the organizational support they received. However, the private sector respondents were slightly more satisfied with the 'faculty role during online education' as compared to the institutional support they 
received. The students from private sector universities were also slightly more satisfied (mean $=2.58)$ than the public sector university students (mean $=2.35$ ) with the 'faculty role during online education'. Likewise, positively influential factors also showed that the students from private sector universities were slightly more satisfied (mean $=2.90)$ than the students from public sector universities (mean $=2.73$ ).

Table 7. Difference of opinions based on the gender.

\begin{tabular}{|c|c|c|c|c|c|c|}
\hline \multirow{2}{*}{ Variable } & \multicolumn{2}{|c|}{ Male } & \multicolumn{2}{|c|}{ Female } & \multirow{2}{*}{$\mathbf{T}$} & \multirow{2}{*}{ Sig } \\
\hline & $\mathbf{N}$ & Mean & $\mathbf{N}$ & Mean & & \\
\hline $\begin{array}{c}\text { Organizational support in facilitating } \\
\text { online education }\end{array}$ & 266 & 2.03 & 440 & 266 & 0.86 & 0.38 \\
\hline $\begin{array}{l}\text { Instructors' role in facilitating } \\
\text { online education }\end{array}$ & 266 & 2.41 & 440 & 2.37 & 0.52 & 0.60 \\
\hline $\begin{array}{l}\text { Positively influential factors in } \\
\text { online education }\end{array}$ & 266 & 2.81 & 440 & 2.73 & 1.22 & 0.22 \\
\hline $\begin{array}{l}\text { Negatively influential factors in } \\
\text { online education }\end{array}$ & 265 & 3.24 & 440 & 3.35 & 1.41 & 0.15 \\
\hline $\begin{array}{l}\text { Students' preference for online classes in } \\
\text { the future }\end{array}$ & 265 & 2.00 & 440 & 1.71 & 3.31 & 0.00 \\
\hline
\end{tabular}

Table 8. Difference of opinions based on the type of university (public or private).

\begin{tabular}{|c|c|c|c|c|c|c|}
\hline \multirow{2}{*}{ Variable } & \multicolumn{2}{|c|}{ Public } & \multicolumn{2}{|c|}{ Private } & \multirow{2}{*}{$\mathbf{T}$} & \multirow{2}{*}{ Sig } \\
\hline & $\mathbf{N}$ & Mean & $\mathbf{N}$ & Mean & & \\
\hline $\begin{array}{c}\text { Organizational support in facilitating } \\
\text { online education }\end{array}$ & 586 & 1.95 & 118 & 2.22 & 3.2 & 0.00 \\
\hline $\begin{array}{l}\text { Instructors' role in facilitating } \\
\text { online education }\end{array}$ & 586 & 2.35 & 118 & 2.58 & 2.6 & 0.00 \\
\hline $\begin{array}{l}\text { Positively influential factors in } \\
\text { online education }\end{array}$ & 586 & 2.73 & 118 & 2.90 & 2.11 & 0.03 \\
\hline $\begin{array}{l}\text { Negatively influential factors in } \\
\text { online education }\end{array}$ & 586 & 3.30 & 118 & 3.33 & 0.71 & 0.75 \\
\hline $\begin{array}{l}\text { Students' preference for online classes in } \\
\text { the future }\end{array}$ & 587 & 1.81 & 118 & 1.91 & 0.88 & 0.37 \\
\hline
\end{tabular}

\subsubsection{Difference of Opinions Based on the Level of Academic Degrees}

Table 9 presents the ANOVA test results based on student types. They show that four out of five variables had a significant difference of opinion and no significant difference existed on negatively influenced factors. The graduate and undergraduate students were not satisfied with the 'university input/level of support' with the mean scores of 1.91 and 1.97 respectively, however, the research students seemed to be slightly satisfied (mean = 2.36). The students' perception of the quality of education also revealed that undergraduate and graduate students were not satisfied, while the research students were neutral in this regard.

\subsubsection{Difference of Opinions Based on Academic Disciplines}

Table 10 shows the ANOVA test results of five variables based on the academic discipline. There was no significant difference of opinion found on all variables based on the academic disciplines of the students. 
Table 9. Difference of opinions based on the level of academic degrees.

\begin{tabular}{|c|c|c|c|c|c|c|c|c|c|c|}
\hline \multirow{2}{*}{ Variable } & \multicolumn{2}{|c|}{$\begin{array}{c}\text { Under } \\
\text { Graduate }\end{array}$} & \multicolumn{2}{|c|}{ Graduate } & \multicolumn{2}{|c|}{$\begin{array}{c}\text { Post } \\
\text { Graduate }\end{array}$} & \multicolumn{2}{|c|}{ Overall } & \multirow[t]{2}{*}{$\mathbf{F}$} & \multirow[t]{2}{*}{ Sig } \\
\hline & $\mathbf{N}$ & Mean & $\mathbf{N}$ & Mean & $\mathbf{N}$ & Mean & $\mathbf{N}$ & Mean & & \\
\hline $\begin{array}{l}\text { Organizational support in } \\
\text { facilitating online education }\end{array}$ & 436 & 1.97 & 199 & 1.91 & 71 & 2.36 & 707 & 1.99 & 8.35 & 0.00 \\
\hline Instructors' role in facilitating online education & 436 & 2.34 & 199 & 2.33 & 71 & 2.86 & 707 & 2.39 & 11.89 & 0.00 \\
\hline Positively influential factors in online education & 436 & 2.73 & 199 & 2.69 & 71 & 3.15 & 707 & 2.76 & 10.41 & 0.00 \\
\hline Negatively influential factors in online education & 435 & 3.37 & 199 & 3.24 & 71 & 3.11 & 706 & 3.31 & 2.77 & 0.06 \\
\hline Students' preference for online classes in the future & 436 & 1.76 & 199 & 1.88 & 71 & 2.08 & 707 & 1.82 & 2.87 & 0.05 \\
\hline
\end{tabular}

Table 10. Difference of opinions based on academic disciplines.

\begin{tabular}{|c|c|c|c|c|c|c|c|c|c|c|}
\hline Variables & $\begin{array}{l}\text { Social } \\
\text { Sciences }\end{array}$ & Sciences & $\begin{array}{c}\text { Engineering } \\
\text { and } \\
\text { Technology }\end{array}$ & $\begin{array}{l}\text { Business/ } \\
\text { Commerce }\end{array}$ & $\begin{array}{l}\text { Arts and } \\
\text { Humanities }\end{array}$ & Agriculture & Health & $\begin{array}{l}\text { Overall } \\
\text { Mean }\end{array}$ & $\mathbf{F}$ & Sig \\
\hline $\begin{array}{l}\text { Organizational support in } \\
\text { facilitating online } \\
\text { education }\end{array}$ & 2.05 & 2.00 & 2.02 & 1.92 & 1.93 & 1.91 & 2.04 & 1.99 & 0.47 & 0.82 \\
\hline $\begin{array}{l}\text { Instructors' role in } \\
\text { facilitating online } \\
\text { education }\end{array}$ & 2.47 & 2.37 & 2.38 & 2.22 & 2.46 & 2.28 & 2.56 & 2.39 & 1.35 & 0.22 \\
\hline $\begin{array}{c}\text { Positively influential } \\
\text { factors in online education }\end{array}$ & 2.78 & 2.79 & 2.74 & 2.78 & 2.83 & 2.66 & 2.63 & 2.76 & 0.51 & 0.79 \\
\hline $\begin{array}{c}\text { Negatively influential } \\
\text { factors in online education }\end{array}$ & 3.21 & 3.37 & 3.36 & 3.26 & 3.14 & 3.57 & 3.41 & 3.31 & 1.76 & 0.10 \\
\hline $\begin{array}{l}\text { Students' preference for } \\
\text { online classes in the future }\end{array}$ & 1.93 & 1.75 & 1.90 & 1.76 & 1.87 & 1.63 & 1.73 & 1.82 & 0.85 & 0.52 \\
\hline
\end{tabular}

\section{Discussion}

The purpose of this study was to examine the perceptions of Pakistani students regarding online learning during the COVID-19 pandemic. The majority of the students have reported negative feelings about their online learning experience due to issues related to institutional support and guidance, technical assistance, methods and modes of instruction and examination, communication, resource readiness and students' home study environment.

\subsection{Organizational Factors in Facilitating Online Education}

\subsubsection{Administrative Support for the Institute}

Organizational support is a critical factor that determines students' level of satisfaction in online environments. The provision of efficient technical support is also important for the establishment of effective online learning environments $[49,83]$. The need for systemic support and guidance [10], including clear indications and implementation of ICT policies [54], has become necessary for the delivery of effective online education during the COVID 19 pandemic. The study results have highlighted a strong level of dissatisfaction among the students in higher education in Pakistan due to a lack of technical support and opportunities for registering complaints and grievances in their educational institutes. Students also indicated that policies on the transition to online education, guidance on access and use of learning management systems, and the availability of learning materials and resources were not satisfactory. Researchers have previously had similar results. Soroya et al. has pointed out that institutes in developing countries may find it challenging to prepare for and respond to emergency management needs [41]. Since students' satisfaction with online education depends on high quality, useful and relevant e-learning systems [84], and their awareness of educational technologies and tools [52], the absence of the needed support and guidance from the institutes significantly contributed towards students' dissatisfaction in our surveyed student population. 


\subsubsection{Instructors' Role in Facilitating Online Education}

Factors such as the 'instructor quality, clarity of assignments and tasks, quality of instructional material, and course communication' are considered important for ensuring positive student experiences while studying online [57]. Flexibility, communication, adjusted timelines, and revised exam formats can help provide resilience, especially during crises situations such as the pandemic [8]. In contrast to the findings of Akram, Anjum, and Batool [26] where $93 \%$ of the students in their study were satisfied with their online tutor, the students in our study were not highly satisfied with the role of instructors in facilitating the students during online learning. Much has been discussed about the importance of timely and constructive feedback in online environments [15,58,59] and the role of timely responses from instructors in contributing towards positive perceptions about online courses [21]. The students were most dissatisfied with the conveniences offered to them in arranging exam schedules, timely and continuous feedback, instructor follow-up, and motivation to improve their academic performance. These findings are similar to those of a study by [62] who reported that communicating with instructors and receiving feedback were some of the biggest challenges in online education.

One possible reason for this could be that the instructors around the world had to make hasty and experimental decisions and resorting to 'learning by doing approaches' [2]. Therefore, the outcomes of the rapidly adopted teaching approaches could only be clarified as the courses progressed [85]. Other hurdles for instructors could be technological limitations, lack of administrative support, and training issues [22,75].

\subsubsection{Modes of Communication Used in Online Education}

The usage of synchronous as well as asynchronous modes of instruction could be an effective way to communicate when face-to-face interaction is not possible [63]. Recent literature suggests that students, caught up in the pandemic, have preferred using recorded lectures or live classes which can be recorded [71]. Similar to the findings of [28] who noted that instructors used a variety of teaching methodologies and modes of communication, our study also indicates the use of online lectures (google hangouts, zoom, skype etc.) with limited use of recorded lectures and social media applications followed by email correspondence. Online learning enables students to advance their knowledge through the exploration of relevant literature and websites [78]. However, it is worth noting that additional literature and course websites were the least used methods of communication by the instructors. Possible reasons for this could be that most universities only shifted to online instruction as a necessary measure but did not have the required time, resources, or willingness to create or develop effective online course websites.

\subsubsection{Assessment Methods Used in Online Education}

It has been argued that the traditional methods of assessing students' success might not be appropriate in online settings [58]. However, instructors in many universities are generally not allowed to make decisions regarding examination systems on their own, even though they do have considerable flexibility in choosing the strategies for assignments and class activities. Interestingly, the instructors were using a variety of assessment methods in assignments including individual as well as group assignments, group discussions, and juries/presentations. The traditional written examinations were found to be the least preferred or used method of assessment. This is understandable given the inherent difficulties in conducting written examinations online due to the closure of educational institutes and physical distancing policies.

\subsubsection{Home Study Environment and Resource Readiness}

The biggest challenge reported by students was the quality of the outside or surrounding environment, which was found to be unsupportive for online study. Poor housing and social conditions can be a major deterrent for families under economic pressure and hinder students' learning [8]. Especially during the lockdown, finding a suitable and quiet 
place to study at home could be difficult $[64,67]$. It is interesting to note that even with the majority of students reporting to live in 3 or above bed apartment/house (39\%) and 1 or 2 bed apartments / houses (36\%), only 35\% students have an independent room for studying.

Similar to the findings of Louis-Jean and Cenat [9], who found that students during the pandemic had limited or no internet access and learning support devices, access to internet emerged as one of the biggest challenges for the students in this study, however, learning support devices were found to be comparatively better. Other researchers have also reported $[7,33,35,37,42,44,54]$ that having a reliable internet connection could be a challenge for students during these times.

\subsection{Positively Influential Factors in Online Education}

Since the students do not have to travel long distances to obtain an education while engaged in online learning, they could save on transportation charges [52]. Concurrent to the findings of Hussein, Daoud, Alrabaiah and Badawi [82], the students in this study considered saving transportation cost as an advantage. It has previously been noted that online learning contributes to developing different skills, such as browsing, searching, information gathering etc. [78] as well as knowledge about computer software and hardware [25]. It is, therefore, promising to note that students also felt an improvement in their command to use relevant software and tools during this time. However, since time management could be challenging for students during online learning [51,52,54,62,80], the students did not feel an improvement in their time management skills. Literature suggests that it could be difficult to arouse interest among students in online environments [78] and being attentive while learning online could be challenging [23]. Adnan and Anwar [7] also reported that the students in their study found distance learning to be less motivating than face-to-face learning, similar to our study participants who indicated that they struggled with maintaining motivation and enthusiasm while learning online and found online learning to be inconvenient and inflexible.

It is important to consider that the quality of teaching might not be standardized across all institutions as only a few have their own LMS systems and a dedicated IT team [22]. Moreover, developing strategies to ensure an effective environment for supporting learners takes time [12]. Therefore, the sudden move to online modes of instruction without proper planning and lack of resources required might have played an important role in driving students' perceptions towards dissatisfaction with online education.

\subsection{Negatively Influential Factors in Online Education}

While it is easier to teach theoretical content online, teaching practical knowledge and skills could be challenging in online environments [79], which is why most students recounted a lack of hands-on and practical training as the most influential barrier. Students highly value a sense of belonging and real-time social interaction with their peers and instructors [53], therefore, sacrifices in social interaction with both their peers and instructors were also found to be negatively influential. The lack of interaction might also lead to a lack of development of interpersonal and communication skills, which has also been reported in our study. Other factors such as online learning boredom and lack of sense of place have been highlighted by students. The students have also reported being overwhelmed by their allotted academic tasks and responsibilities. These findings are similar to those of $[49,82]$ who have reported that an increase in student workload was a negative aspect of online learning. Alexander, Truell, and Zhao [72] found that students indicated that understanding content could be harder in online courses. These results are similar to those of our study where the students declared an inability to grasp concepts as a negatively influential factor.

\subsection{Future Preference for Taking Online Courses}

Previously, Akram, Anjum, and Batool [26] have stated that even if students preferred or liked taking online classes during the pandemic, it does not necessarily mean that they 
are going to be satisfied with them as well. Concurrent with the students' opinions in a recent study by [86], the majority of the students we surveyed unequivocally expressed that they would not prefer taking online classes in the future. These findings are also in congruence with those of [27], in which $77 \%$ of the medical students had negative responses regarding the preference of e-learning in the future. However, these findings contradict Dobbs et al. [87], who posited that students who had online experience tended to view it positively and showed an interest in taking online courses in the future. Similarly, [54] also found that all participants of the study indicated their eagerness and willingness to take online courses in the future. This implies that students' experiences tended to differ considerably depending upon the situation and context of the study environment and difference of opinion can exist when online education is offered normally as compared to crisis response. In the current study, issues such as lack of technical support, unclear institutional policies and guidelines, instructors' inability to effectively facilitate online learning, lack of interaction, electricity and internet problems, and the unsuitability of homelearning environments were found to have significantly impacted students' perceptions about online learning during the pandemic.

\subsection{Differences in Students' Opinions and Perceptions Based on Selected Variables}

In terms of individual differences, our study reveals that while male and female students have similar opinions regarding the organizational support and instructor's role as well as positively and negatively influential factors, male students have a stronger opinion for not preferring online education the future. However, in contrast to the findings of [28], who found that students from private sector universities were more dissatisfied with their online experiences, our study reveals that public sector university students are more dissatisfied with their overall experiences of online education. This may be attributed to a generally improved infrastructure acquired by the private sector universities. On the other hand, students enrolled in postgraduate degrees (M.Phil., Ph.D.) were found to be slightly more satisfied with the online education experiences. One possible explanation for this is that usually postgraduate students are more adept to self-directed study, need less supervision from their instructors, and have limited lectures to attend as compared to students enrolled in undergraduate and graduate programs. Another reason could be a higher level of 'readiness towards computer/internet, online communication, self-efficacy and learning motivation', as was reported by [76]. When looking for difference of opinions based on academic disciplines, our study found that the surveyed students had similar experiences regarding all variables. These findings call for an overall improvement in terms of institutional support, instructors' role as well as coordinated efforts in overcoming the challenges faced by the students during online learning.

\section{Implications of the Study}

\subsection{Theoretical Implications}

This is a comprehensive study exploring students' perceptions and experiences related to online education in Pakistan. It also addresses a gap in the literature by investigating all-inclusive vital factors such as the role of university and instructor support during online education, positive and negative influential factors associated with the online environments, and the effects of the home study environment and resource readiness on online education in a developing country's context with limited resources, infrastructure, and facilities.

\subsection{Practical Implications}

The study was conducted when almost all the institutions of the country had shifted from the face-to-face mode of instruction to online/distance learning modes. One of the most critical elements was the lack of coherent coordination among various relevant institutions and governmental ministries. Almost half of the Pakistani population belongs to rural areas where there are recognizable technological issues. The relevant institutions need to frame a feasible infrastructure to ensure that all students are able to continue their 
education online. Since there are digital libraries in Punjab Province and these libraries are equipped with the latest tools and infrastructure, they can be used for virtual classes.

However, this demands an effective cooperation among the Higher Education Commission (HEC), higher education institutions (HEIs), the Pakistan Telecommunication Authority (PTA), and the Ministry of Information Technology and Telecommunication (MoITT). HEC and HEIs should also focus on providing training to their instructors in online driven competencies such as planning, implementing, and assessing students' performance in online settings.

\subsection{Limitations and Future Research Directions}

We would like to point out some limitations of the present study. First, it should be noted that most institutes and students in the study were not familiarized with or prepared for shifting to online teaching and learning modalities at the time of the study. Some institutes might since have improved their capacities and capabilities related to online education leading to changed students' perceptions. It is possible that over time respondents' opinions might have changed regarding online education and its prospects in Pakistan.

Second, our study has focused only on the self-evaluated and self-reported perceptions of students. A sequential mix-method study in the future might help explore the topic further. Future research could also involve a qualitative study exploring the opinions of all major stakeholders, i.e., students, teachers, administrators, and HEC officials to investigate the impact of online education in the country and to improve the quality of online education during crises situations and beyond.

\section{Conclusions}

Although educational institutes around the world have resorted to emergency remote teaching or online education in response to the various crisis and disaster situations in the past $[81,88-90]$, this is the first time that the educational sector has been unnerved due to the global scale of the pandemic. The results of the current study indicate that the students are not satisfied with the overall experience of online education in Pakistan during the COVID-19 pandemic. Understandably, adapting to new learning and teaching modalities is difficult for students as well as instructors [9]. Even those with prior experience of online education modalities have had to adapt to new methods of teaching during this sudden shift from traditional teaching methodologies [10]. However, despite all the difficulties, faculty members teaching online during this phase have made necessary course modifications to cope with these challenges and to provide some relief to the students and ensuring the continuity of education $[8,10,63]$. The students and other stakeholders need to understand that this has been a challenging and novel situation for the educators and administrators of academic institutes. Their IT infrastructure and other resource capacities might not have been fit for purpose and may have been overwhelmed by the sudden transition, impacting the overall student experience.

On the other hand, the COVID-19 crisis has also opened new horizons for exploring flexible learning possibilities. Perhaps the best course of action in situations like this is providing education through blended methods $[2,54,63]$. Even though online or blended education is not a widespread concept in most HEIs and universities in Pakistan, the current pandemic has allowed and 'forced' most institutes to explore new avenues which, if planned and implemented properly, may even become norms in these universities in the future. This may also be beneficial to institutes with predominantly poorly built infrastructure and lack of space issues affecting traditional face-to-face teaching and learning.

Since the universities in the public and private sectors have varying resources and infrastructure capacities, a variety of teaching techniques and learning systems have been used by these institutes. This has resulted in varied outcomes in terms of teaching and learning across the country. During the pandemic, different government bodies like the HEC Pakistan, the Punjab Higher Education Department, the National Academy of Higher 
Education, and various institutes like the Virtual University have helped each other in strengthening their online systems. Moving forward there is a need for the HEIs and universities, under the aegis of HEC, to try to develop mechanisms and operational guidelines that enable them to act swiftly in response to similar crises situations in the future. In this regard, proper infrastructure, facilities as well as training opportunities for teachers should be considered. While each institute may have to develop its policies, procedures, guidelines, and contingencies for such situations according to its organizational capacities, efforts must be made to align them with the directives and guidelines put forth by the relevant government bodies. This would ensure that the teaching and learning processes become standardized for universities and higher education institutes across the country.

Author Contributions: Conceptualization, S.A.I. and M.A.; methodology, S.U.R.; software, S.U.R.; validation, S.R.; formal analysis, N.T.; writing—original draft preparation, S.A.I., M.A., S.U.R. and S.R.; writing-review and editing, S.R.; supervision, S.R. All authors have read and agreed to the published version of the manuscript.

Funding: This research received no external funding.

Institutional Review Board Statement: For ensuring ethical considerations, the study was reviewed and approved by the Institute of Information Management, University of the Punjab, Lahore. Informed consent was obtained from all the respondents of the study. Furthermore, the respondents were ensured that their identity will not be disclosed, and the data will be used for research purposes only. Data were collected after taking permission from the concerned departments and after the consent of the respondents. A cover letter for the questionnaire explaining research objectives and fair use of the data was prepared for informed consent, and no personal data of the participants (name, email, phone number) was collected. After reading the cover letter the participants who agreed filled the questionnaires.

Informed Consent Statement: Informed consent was obtained from all subjects involved in the study.

Data Availability Statement: Data are available on request to the corresponding author.

Acknowledgments: The authors would like to acknowledge the support of Prince Sultan University for paying the Article Processing Charges (APC) of this publication.

Conflicts of Interest: The authors declare no conflict of interest.

\section{Appendix A}

Greetings and Assalam o Alaikum! Our research team is exploring the extent and quality of online teaching and learning offered by different universities in the wake of the COVID-19 pandemic. Your valuable feedback and opinions would greatly help us to analyze key factors involved and deduce some valuable insights for possibly improving the quality of online education in the future. Please note that the survey is intended for UNIVERSITY STUDENTS who have experience of taking ONLINE CLASSES previously. Your responses will be confidential and data gathered will be reported only in the aggregate. It will take you approximately $5 \mathrm{~min}$ to complete the questionnaire. Should you have any questions about the survey, you may contact Mr. Murtaza Ashiq at gmurtazaashiq00@gmail.com Thank you in advance for your time and support. To start responding, please click on the Next button below.

\section{Demographic Information}

1. What is your gender:
a. Male

b. Female

2. Which category of university are you enrolled in?
a. Public (Government) University
b. Private University 
3. What is your enrollment level?
a. Undergraduate Degree (B.A, B.Sc etc.)
b. Graduate Degree (M.A, M.Sc, etc.)
c. Research Student (M.Phil/Ph.D)

4. What is the name of your University or Degree Awarding Institute?

\section{Text box}

5. Which discipline are you enrolled in?
a. Arts and Humanities
b. Social Sciences
c. Sciences
d. Health Sciences
e. Engineering and Technology
f. Business/Management/Commerce
g. Agriculture
h. Education
i. Other

6. What is your area of specialization/Degree/Department

\section{Section I-Home Study Environment}

1. Which type of accommodation do you have?
a. Room on rent
b. Public or Private Hostel
c. Single Bed Apartment/Studio Apartment
d. 1-2 Bed Apartment/House
e. 3 or above Bed Apartment/House

2. What type of arrangement do you have for studying?

a. An independent study area/room

b. A shared study area/room

3. Please rate the following factors related to the home study environment during online learning:

\begin{tabular}{|c|c|c|c|c|c|}
\hline & Poor & Fair & Good & Very Good & Excellent \\
\hline $\begin{array}{l}\text { 1. The level of in-house support and } \\
\text { facilitation from } \\
\text { family/friends/roommates etc. } \\
\text { to concentrate }\end{array}$ & $\square$ & $\square$ & $\square$ & $\square$ & $\square$ \\
\hline $\begin{array}{l}\text { 2. The quality of outside/surrounding } \\
\text { environment (background sounds, } \\
\text { noises, unnecessary disruption etc.) }\end{array}$ & $\square$ & $\square$ & $\square$ & $\square$ & $\square$ \\
\hline 3. The quality of internet connection & $\square$ & $\square$ & $\square$ & $\square$ & $\square$ \\
\hline $\begin{array}{l}\text { 4. The availability of power supply } \\
\text { (electricity) in your area }\end{array}$ & $\square$ & $\square$ & $\square$ & $\square$ & $\square$ \\
\hline $\begin{array}{l}\text { 5. The availability of required devices } \\
\text { and facilities (computer/tablet, } \\
\text { cellphone, printer, study table, etc.) }\end{array}$ & $\square$ & $\square$ & $\square$ & $\square$ & $\square$ \\
\hline
\end{tabular}




\section{Section II-University's Input/Level of Support}

1. Please rate the following factors related to the University's support given for online education:

\begin{tabular}{|c|c|c|c|c|c|}
\hline & $\begin{array}{l}\text { Not at all } \\
\text { Satisfied }\end{array}$ & $\begin{array}{l}\text { Slightly } \\
\text { Satisfied }\end{array}$ & $\begin{array}{l}\text { Moderately } \\
\text { Satisfied }\end{array}$ & $\begin{array}{c}\text { Very } \\
\text { Satisfied }\end{array}$ & $\begin{array}{c}\text { Extremely } \\
\text { Satisfied }\end{array}$ \\
\hline $\begin{array}{l}\text { 1. Clear guidelines/policies on } \\
\text { shifting from traditional to the } \\
\text { online mode of education. }\end{array}$ & 口 & $\square$ & $\square$ & ב & ב \\
\hline $\begin{array}{l}\text { 2. Guidance/tutorials on the } \\
\text { access and use of learning } \\
\text { management systems or other } \\
\text { modes of online education. }\end{array}$ & $\square$ & $\square$ & 口 & ב & $\square$ \\
\hline $\begin{array}{l}\text { 3. Availability of learning material } \\
\text { and library resources for } \\
\text { course completion. }\end{array}$ & 口 & 口 & 口 & $\square$ & 口 \\
\hline $\begin{array}{l}\text { 4. Technical support to overcome } \\
\text { any technical difficulties. }\end{array}$ & 口 & $\square$ & 口 & 口 & 口 \\
\hline $\begin{array}{l}\text { 5. Provision for registering any } \\
\text { grievances or complaints. }\end{array}$ & $\square$ & $\square$ & $\square$ & $\square$ & $\square$ \\
\hline
\end{tabular}

\section{Section III-Faculty's Role and Input in the Delivery of Courses}

1. Which modes of communication were used by your instructors for online teaching (select all that may apply):
a. Course Websites
b. E-mail Correspondence
c. Online Lectures/Video Conferencing (Google hangouts, Zoom, Skype, etc.)
d. Recorded Lectures
e. Social Media apps (WhatsApp/Facebook, etc.)
f. Other website links (for reading material)

2. Which types of assessment methods were used by your instructors for online teaching (select all that may apply):
a. One-to-one discussions
b. Group discussions
c. Individual assignments
d. Group assignments
e. Oral/written quizzes
f. Written examinations
g. Juries/Presentations
h. Other

3. Please rate the following factors related to the Faculty's role in providing online education:

\begin{tabular}{lccccc}
\hline & $\begin{array}{c}\text { Not at all } \\
\text { Satisfied }\end{array}$ & $\begin{array}{c}\text { Slightly } \\
\text { Satisfied }\end{array}$ & $\begin{array}{c}\text { Moderately } \\
\text { Satisfied }\end{array}$ & $\begin{array}{c}\text { Very } \\
\text { Satisfied }\end{array}$ & $\begin{array}{c}\text { Extremely } \\
\text { Satisfied }\end{array}$ \\
\hline 1. The overall Quality of Course Content & $\square$ & $\square$ & $\square$ & $\square$ & $\square$ \\
\hline 2. In-time delivery of course content & $\square$ & $\square$ & $\square$ & $\square$ \\
\hline 3. Appropriate pace of lectures & $\square$ & $\square$ & $\square$ & $\square$ & $\square$ \\
\hline $\begin{array}{l}\text { 4. Opportunities given to ask questions } \\
\text { 5. Clear guidelines about assignments } \\
\text { and assessments }\end{array}$ & $\square$ & $\square$ & $\square$ & $\square$ & $\square$ \\
\hline $\begin{array}{l}\text { 6. Flexibility in following } \\
\text { assignment deadlines }\end{array}$ & $\square$ & $\square$ & $\square$ & $\square$ & $\square$ \\
\hline $\begin{array}{l}\text { 7. Convenient exam schedules } \\
\text { 8. Timely and continuous feedback on } \\
\text { class progress }\end{array}$ & $\square$ & $\square$ & $\square$ & $\square$ & $\square$ \\
\hline $\begin{array}{l}\text { 9. Follow-up and motivation to improve } \\
\text { class progress }\end{array}$ & $\square$ & $\square$ & $\square$ & $\square$ \\
\hline $\begin{array}{l}\text { 10. Availability for consultation and } \\
\text { guidance after class hours (WhatsApp, } \\
\text { Messages, E-mails, etc.) }\end{array}$ & $\square$ & $\square$ & $\square$ & $\square$ \\
\hline
\end{tabular}




\section{Section IV-Students' Personal Input and Experience}

1. Please rate the following statements related to your personal feelings and experiences after taking online classes:

\begin{tabular}{|c|c|c|c|c|c|}
\hline & $\begin{array}{l}\text { Strongly } \\
\text { Disagree }\end{array}$ & Disagree & Neutral & Agree & $\begin{array}{c}\text { Strongly } \\
\text { Agree }\end{array}$ \\
\hline $\begin{array}{l}\text { 1. I was able to maintain motivation and } \\
\text { enthusiasm while taking online classes. }\end{array}$ & $\square$ & $\square$ & $\square$ & $\square$ & $\square$ \\
\hline $\begin{array}{l}\text { 2. I was able to manage my time } \\
\text { effectively (completing assignments, } \\
\text { assessments, etc.) }\end{array}$ & $\square$ & $\square$ & $\square$ & $\square$ & $\square$ \\
\hline $\begin{array}{l}\text { 3. I found online learning to be more } \\
\text { convenient and flexible }\end{array}$ & $\square$ & $\square$ & $\square$ & $\square$ & $\square$ \\
\hline $\begin{array}{l}\text { 4. I was quite successful in using the } \\
\text { relevant software and required tools. }\end{array}$ & $\square$ & ב & $\square$ & 口 & $\square$ \\
\hline $\begin{array}{l}\text { 5. I was able to cut down } \\
\text { transportation costs. }\end{array}$ & $\square$ & 口 & $\square$ & $\square$ & $\square$ \\
\hline $\begin{array}{l}\text { 6. I was able to focus on additional } \\
\text { things (part-time job, hobbies etc.) }\end{array}$ & $\square$ & ב & $\square$ & D & $\square$ \\
\hline $\begin{array}{l}\text { 7. My command in using the relevant } \\
\text { software and required tools } \\
\text { has increased. }\end{array}$ & $\square$ & $\square$ & $\square$ & $\square$ & $\square$ \\
\hline $\begin{array}{l}\text { 8. My ability to practice } \\
\text { self-responsibility has increased. }\end{array}$ & $\square$ & a & 口 & $\square$ & $\square$ \\
\hline $\begin{array}{l}\text { 9. My ability to practice self-discipline } \\
\text { has increased. }\end{array}$ & $\square$ & $\square$ & $\square$ & $\square$ & $\square$ \\
\hline $\begin{array}{l}\text { 10. My time-management skills } \\
\text { have increased. }\end{array}$ & $\square$ & $\square$ & $\square$ & $\square$ & $\square$ \\
\hline
\end{tabular}

2. Were any of the following factors 'negatively influential' on your online learning? (Select as many as apply)

\begin{tabular}{lccccc}
\hline & $\begin{array}{c}\text { Not at all } \\
\text { Influential }\end{array}$ & $\begin{array}{c}\text { Slightly } \\
\text { Influential }\end{array}$ & $\begin{array}{c}\text { Somewhat } \\
\text { Influential }\end{array}$ & $\begin{array}{c}\text { Very } \\
\text { Influential }\end{array}$ & $\begin{array}{c}\text { Extremely } \\
\text { Influential }\end{array}$ \\
\hline 1. Disruption in sleeping pattern & $\square$ & $\square$ & $\square$ & $\square$ & $\square$ \\
\hline $\begin{array}{l}\text { 2. Online learning boredom/difficulty } \\
\text { in concentrating }\end{array}$ & $\square$ & $\square$ & $\square$ & $\square$ & $\square$ \\
\hline $\begin{array}{l}\text { 3. Inability to grasp concepts, learning } \\
\text { objectives effectively }\end{array}$ & $\square$ & $\square$ & $\square$ & $\square$ & $\square$ \\
\hline $\begin{array}{l}\text { 4. Feeling overburdened with academic } \\
\text { tasks and responsibilities }\end{array}$ & $\square$ & $\square$ & $\square$ & $\square$ \\
\hline 5. Lack of sense of place & $\square$ & $\square$ & $\square$ & $\square$ \\
\hline $\begin{array}{l}\text { 6. Lack of sense of } \\
\text { time/irregular routine }\end{array}$ & $\square$ & $\square$ & $\square$ & $\square$ \\
\hline 7. Lack of student-student interaction & $\square$ & $\square$ & $\square$ & $\square$ & $\square$ \\
\hline $\begin{array}{l}\text { 8. Lack of student-teacher interaction } \\
\text { 9. Lack of hands-on/practical training }\end{array}$ & $\square$ & $\square$ & $\square$ & $\square$ & $\square$ \\
\hline $\begin{array}{l}\text { 10. Lack of interpersonal and } \\
\text { communication skills }\end{array}$ & $\square$ & $\square$ & $\square$ & $\square$ & $\square$ \\
\hline
\end{tabular}

\section{Section V-Students' Opinions for Delivery of Online Education in the Future}

1. Would you like to take online classes in the future even after the COVID-19 outbreak is over?
a. Very unlikely
b. Unlikely
c. Neutral
d. Likely
e. Very likely

Please write any additional comments/suggestions to help improve the quality of online teaching and learning by universities in the future. 


\section{References}

1. Koh, D. COVID-19 lockdowns throughout the world. Occup. Med. 2020, 70, 322. [CrossRef]

2. Marinoni, G.; Land, H.V.t.; Jensen, T. The Impact of COVID-19 on Higher Education Around the World-IAU Global Survey Report; International Association of Universities: Paris, France, 2020.

3. Crawford, J.; Butler-Henderson, K.; Rudolph, J.; Malkawi, B.; Glowatz, M.; Burton, R.; Magni, P.A.; Lam, S. COVID-19: 20 countries' higher education intra-period digital pedagogy responses. J. Appl. Learn. Teach. 2020, 3, 1-20. [CrossRef]

4. O'Keefe, L.; Rafferty, J.; Gunder, A.; Vignare, K. Delivering High-Quality Instruction online in Response to COVID-19: Faculty Playbook. Available online: https:/ / files.eric.ed.gov/fulltext/ED605351.pdf (accessed on 23 January 2021).

5. International Association of Universities. COVID-19: Higher Education Challenges and Responses. Available online: https: //www.iau-aiu.net/Covid-19-Higher-Education-challenges-and-responses (accessed on 1 July 2021).

6. UNESCO. Education: From Disruption to Recovery. Available online: https://en.unesco.org/covid19/educationresponse (accessed on 25 July 2021).

7. Adnan, M.; Anwar, K. Online Learning amid the COVID-19 Pandemic: Students' Perspectives. J. Pedagog. Sociol. Psychol. 2020, 2, 45-51. [CrossRef]

8. Kalloo, R.C.; Mitchell, B.; Kamalodeen, V.J. Responding to the COVID-19 pandemic in Trinidad and Tobago: Challenges and opportunities for teacher education. J. Educ. Teach. 2020, 46, 452-462. [CrossRef]

9. Louis-Jean, J.; Cenat, K. Beyond the face-to-face learning: A contextual analysis. Pedagog. Res. 2020, 5, 1-4. [CrossRef]

10. Johnson, N.; Veletsianos, G.; Seaman, J.U.S. Faculty and administrators' experiences and approaches in the early weeks of the COVID-19 Pandemic. Online Learn. 2020, 24, 6-21. [CrossRef]

11. Osman, M.E. Global impact of COVID-19 on education systems: The emergency remote teaching at Sultan Qaboos University. J. Educ. Teach. 2020, 46, 463-471. [CrossRef]

12. Hodges, C.; Moore, S.; Lockee, B.; Trust, T.; Bond, A. The Difference between Emergency Remote Teaching and Online Learning Available online: https:/ / er.educause.edu/articles/2020/3/the-difference-between-emergency-remote-teaching-and-onlinelearning (accessed on 25 July 2021).

13. Palvia, S.; Aeron, P.; Gupta, P.; Mahapatra, D.; Parida, R.; Rosner, R.; Sindhi, S. Online education: Worldwide status, challenges, trends, and implications. J. Glob. Inf. Technol. Mang. 2018, 21, 233-241. [CrossRef]

14. Ternus, M.P.; Palmer, K.L.; Faulk, D.R. Benchmarking Quality in Teaching \& Learning. J. Eff. Teach. 2007, 7, 51-67.

15. Mayes, R.; Luebeck, J.; Ku, H.-Y.; Akarasriworn, C.; Korkmaz, Ö. Themes and strategies for transformative online instruction: A review of literature and practice. Q. Rev. Distance Educ. 2011, 12, 151-166, 221-222.

16. Maddux, C. Developing online courses: Ten myths. Rural Spec. Educ. Q. 2004, 23, 27-32. [CrossRef]

17. McPherson, M.; Miguel Baptista, N. Organisational issues for e-learning: Critical success factors as identified by HE practitioners. Int. J. Educ. Manag. 2006, 20, 542-558. [CrossRef]

18. Dumford, A.D.; Miller, A.L. Online learning in higher education: Exploring advantages and disadvantages for engagement. $J$ Comput. High. Educ. 2018, 30, 452-465. [CrossRef]

19. Driscoll, A.; Jicha, K.; Hunt, A.N.; Tichavsky, L.; Thompson, G. Can online courses deliver in-class results? Teach. Sociol. 2012, 40, 312-331. [CrossRef]

20. Brocato, B.R.; Bonanno, A.; Ulbig, S. Student perceptions and instructional evaluations: A multivariate analysis of online and face-to-face classroom settings. Educ. Inf. Technol. 2015, 20, 37-55. [CrossRef]

21. Jackson, L.C.; Jones, S.J.; Rodriguez, R.C. Faculty actions that result in student satisfaction in online courses. J. Asynchronous Learn. Netw. 2010, 14, 78-96. [CrossRef]

22. Farooq, F.; Rathore, F.A.; Mansoor, S.N. Challenges of online medical education in Pakistan during COVID-19 pandemic. J. Coll. Physicians Surg. Pak. 2020, 30, 67-69. [CrossRef]

23. Mukhtar, K.; Javed, K.; Arooj, M.; Sethi, A. Advantages, limitations and recommendations for online learning during COVID-19 pandemic era. Pak. J. Med. Sci. 2020, 36, S27-S31. [CrossRef]

24. Rehman, M.M. Online Education in Pakistan in COVID-19 Era. Available online: https://dailytimes.com.pk/600452/onlineeducation-in-pakistan-in-covid-19-era/ (accessed on 17 June 2021).

25. Akhter, H.; Mahmood, M. Study of the Impact of online education on student's learning at university level in Pakistan. Int. J. Distance Educ. E-Learn. 2018, 3, ED597924.

26. Akram, M.; Anjum, F.; Batool, Z. COVID-19: A reason behind digital education in Pakistan. Mediterr. J. Soc. Sci. 2020, 11, 19-26. [CrossRef]

27. Abbasi, S.; Ayoob, T.; Malik, A.; Memon, S.I. Perceptions of students regarding E-learning during COVID-19 at a private medical college. Pak. J. Med. Sci. 2020, 36, S57-S61. [CrossRef] [PubMed]

28. Ansar, F.; Ali, W.; Khattak, A.; Naveed, H.; Zeb, S. Undergraduate students' perception and satisfaction regarding online learning system amidst COVID-19 Pandemic in Pakistan. J. Ayub Med. Coll. Abbottabad 2020, 32, S644-S650.

29. Geo News. Pakistan Latest Victim of Coronavirus. Available online: https://www.geo.tv/latest/274482-pakistan-confirms-first (accessed on 15 July 2021).

30. Stanway, D.; Smith, J. Coronavirus Spreads Faster outside China, Stoking Global Fears. Available online: https://www reuters.com/article/us-china-health/coronavirus-spreads-faster-outside-china-stoking-global-fears-idUSKCN20J0B4 (accessed on 15 July 2021). 
31. Ali, I.; Shah, S.A.; Siddiqui, N. Pakistan Confirms First Two Cases of Coronavirus, Govt Says 'No Need to Panic'. Available online: https: / / www.dawn.com/news/1536792 (accessed on 15 July 2021).

32. Alwis, D.D.; Saif, S.K.; Niazi, S. Universities Shut down across South and Southeast Asia. Available online: https://www. universityworldnews.com/post.php?story=2020032008521144 (accessed on 17 June 2021).

33. Khattak, K. Campuses to Remain Closed till May 31. Available online: https://www.thenews.com.pk/print/635162-campusesto-remain-closed-till-may-31 (accessed on 15 July 2021).

34. MOFEPT Pakistan. Notification No. F.1-1/2020-FEEPT; Islamabad, Ministry of Federal Education and Professional Training: Islamabad, Pakistan, 2020; Volume 1.

35. Khan, A.A.; Niazi, S.; Saif, S.K. Universities Unprepared for Switch to Remote Learning. Available online: https://www. universityworldnews.com/post.php?story=20200326141547229 (accessed on 17 June 2021).

36. The News. HEC Asks Universities to Start Online Teaching. Available online: https://www.thenews.com.pk/print/636738-hecasks-universities-to-start-online-teaching (accessed on 15 July 2021).

37. Gabol, I. Students, Faculty Express Reservations over Online Education System. Available online: https://www.dawn.com/ news / 1545094 (accessed on 15 July 2021).

38. The News. HEC Allows All Public, Private Sector Universities to Commence online Teaching. Available online: https://www thenews.com.pk/print/636759-hec-allows-all-public-private-sector-universities-to-commence-online-teaching (accessed on 15 July 2021).

39. Allama Iqbal Open University Pakistan. An Overview. Available online: https://www.aiou.edu.pk/overview.asp (accessed on 20 July 2021).

40. Virtual University of Pakistan. Introdcution to the University. Available online: http://www.vu.edu.pk/AboutUs/AboutVU.aspx (accessed on 20 July 2021).

41. Soroya, S.H.; Rehman, M.A.; Abbas, Z.; Mirza, F.; Mahmood, K. Emergency management in higher education during COVID-19 pandemic: A phenomenology inquiry comparing a developed and developing country. Libr. Philos. Pract. 2020, 4720, 1-32.

42. Mahmood, A. COVID-19: Education in Pakistan Gets Mundane Attention. Available online: https://www.thenews.com.pk/ print/660617-covid-19-education-in-pakistan-gets-mundane-attention (accessed on 15 July 2021).

43. Dawn News. University Students Threaten Protest against online Classes. Available online: https://www.dawn.com/news/15 60755/university-students-threaten-protest-against-online-classes (accessed on 15 July 2021).

44. Abbasi, K. Students Protest 'Faulty' online System, Charging of Fee by Varsities. Available online: https://www.dawn.com/ news /1563770/students-protest-faulty-online-system-charging-of-fee-by-varsities (accessed on 15 July 2021).

45. Stallings, D. Measuring Success in the Virtual University. J. Acad. Librariansh. 2002, 28, 47-53. [CrossRef]

46. Stickney, L.T.; Bento, R.F.; Aggarwal, A.; Adlakha, V. Online higher education: Faculty satisfaction and its antecedents. J. Manag. Educ. 2019, 43, 509-542. [CrossRef]

47. Hulett, M.T. Online Teaching Strategies \& Best Practices. Ph.D. Thesis, California State University, Los Angeles, CA, USA, 2018.

48. Sahu, P. Closure of universities due to Coronavirus Disease 2019 (COVID-19): Impact on education and mental health of students and academic staff. Cureus 2020, 12, e7541. [CrossRef]

49. Roby, T.; Ashe, S.; Singh, N.; Clark, C. Shaping the online experience: How administrators can influence student and instructor perceptions through policy and practice. Internet High. Educ. 2013, 17, 29-37. [CrossRef]

50. Kundi, G.M.; Nawaz, A.; Khan, S. The predictors of success for e-learning in higher education insitutions in N.W.F.P, Pakistan. J. Inf. Sys. Technol. Manag. 2010, 7, 545-578. [CrossRef]

51. Rajab, M.H.; Gazal, A.M.; Alkattan, K. Challenges to online medical education during the COVID-19 Pandemic. Cureus 2020, 12, e8966. [CrossRef]

52. Hussain, I.; Hussain, I.; Ramzan, M. Future prospects of virtual education in Pakistan: Opportunities and challenges. J. Res. Soc. Sci. 2019, 7, 149-163.

53. Toufaily, E.; Zalan, T.; Lee, D. What do learners value in online education? An emerging market perspective. E-J. Bus. Edu. Scholarsh. Teach. 2018, 12, 24-39.

54. Paudel, P. Online education: Benefits, challenges and strategies during and after COVID-19 in higher education. Int. J. Studies Educ. 2021, 3, 70-85. [CrossRef]

55. Dhawan, S. Online learning: A panacea in the time of COVID-19 Crisis. J. Educ. Technol. Syst. 2020, 49, 5-22. [CrossRef]

56. Govindarajan, V.; Srivastava, A. What the shift to virtual learning could mean for the future of higher ed. Harv. Bus. Rev. 2020, 31, 3-8.

57. Estelami, H. An exploratory study of the drivers of student satisfaction and learning experience in hybrid-online and purely online marketing courses. Mark. Educ. Rev. 2014, 22, 143-156. [CrossRef]

58. Serwatka, J. Improving student performance in distance learning courses. The Journal 2002, 29, 46-51.

59. Martin, F.; Wang, C.; Jokiaho, A.; May, B.; Grübmeyer, S. Examining faculty readiness to teach online: A comparison of US and German educators. Eur. J. Open Distance E-Learn. 2019, 22, 53-69. [CrossRef]

60. Bao, W. COVID-19 and online teaching in higher education: A case study of Peking University. Hum. Behav. Emerg. Technol. 2020, 2, 113-115. [CrossRef] 
61. Martin, A. How to Optimize online Learning in the Age of Coronavirus (COVID-19): A 5-Point Guide for Educators. Available online: https://newsroom.unsw.edu.au/news/social-affairs/how-optimise-online-learning-age-coronavirus (accessed on 17 June 2021).

62. Abramenka, V. Students Motivations and Barriers to Online Education. Master's Thesis, Grand Valley State University, Allendale Charter Township, MI, USA, 2015.

63. Moorhouse, B.L. Adaptations to a face-to-face initial teacher education course 'forced' online due to the COVID-19 pandemic. J. Educ. Teach. 2020, 46, 609-611. [CrossRef]

64. Atreya, A.; Acharya, J. Distant virtual medical education during COVID-19: Half a loaf of bread. Clin. Teach. 2020, 17, 1-2. [CrossRef]

65. Khan, R.A.; Jawaid, M. Technology enhanced assessment (TEA) in COVID 19 Pandemic. Pak. J. Med. Sci. 2020, 36, S108. [CrossRef] [PubMed]

66. Callo, E.C.; Yazon, A.D. Exploring the factors influencing the readiness of faculty and students on online teaching and learning as an alternative delivery mode for the new normal. Univers. J. Educ. Res. 2020, 8, 3509-3518. [CrossRef]

67. Aristovnik, A.; Keržič, D.; Ravšelj, D.; Tomaževič, N.; Umek, L. Impacts of the COVID-19 pandemic on life of higher education students: A global perspective. Sustainability 2020, 12, 8438. [CrossRef]

68. Sun, L.; Tang, Y.; Zuo, W. Coronavirus pushes education online. Nat. Mater. 2020, 19, 687. [CrossRef] [PubMed]

69. Chattaraj, D.; Vijayaraghavan, A.P. Why learning space matters: A script approach to the phenomena of learning in the emergency remote learning scenario. J. Comput. Educ. 2021, 8, 343-364. [CrossRef]

70. Qazi, A.; Naseer, K.; Qazi, J.; AlSalman, H.; Naseem, U.; Yang, S.; Hardaker, G.; Gumaei, A. Conventional to online education during COVID-19 pandemic: Do develop and underdeveloped nations cope alike. Child. Youth Serv. Rev. 2020, $119,105582$. [CrossRef]

71. Muthuprasad, T.; Aiswarya, S.; Aditya, K.S.; Jha, G.K. Students' perception and preference for online education in India during COVID -19 pandemic. Soc. Sci. Hum. Open 2021, 3, 100101. [CrossRef] [PubMed]

72. Alexander, M.W.; Truell, A.D.; Zhao, J.J. Expected advantages and disadvantages of online learning: Perceptions from college students who have not taken online courses. Issues Inf. Syst. 2012, 13, 193-200.

73. Alshamrani, M. An Investigation of the Advantages and Disadvantages of Online Education. Master's Thesis, Auckland University of Technology, Auckland, Newzeland, 2019.

74. Manea, V.I.; Macavei, T.; Pribeanu, C. Perceived benefits of online lectures during the pandemic: A case study in engineering education. Pro Edu Inter. J. Edu. Sci. 2021, 3, 35-41. [CrossRef]

75. Salman, S.A. Role of Faculty in the Effectiveness of Fully Online Programs. Ph.D. Thesis, Nova Southeastern University, Davie, FL, USA, 2013.

76. Rafique, G.M.; Mahmood, K.; Warraich, N.F.; Rehman, S.U. Readiness for online learning during COVID-19 pandemic: A survey of Pakistani LIS students. J. Acad. Librariansh. 2021, 47, 102346. [CrossRef]

77. Mackey, K.R.M.; Freyberg, D.L. The effect of social presence on affective and cognitive learning in an international engineering course taught via distance learning. J. Eng. Educ. 2010, 99, 23-34. [CrossRef]

78. Ogunleye, A.O. Evaluating an online learning programme from students perspectives. J. Coll. Teach. Learn. 2010, 7, 79. [CrossRef]

79. Machado, R.A.; Bonan, P.R.F.; Perez, D.E.d.C.; Martelli Junior, H. COVID-19 pandemic and the impact on dental education: Discussing current and future perspectives. Braz. Oral Res. 2020, 34, 1-6. [CrossRef] [PubMed]

80. Hussain, I. Study on instructional paradigms of virtual education in Pakistan: A learner's perspective. Turk. Online J. Educ. Technol. 2012, 11, 178-186.

81. Seville, E.; Hawker, C.; Lyttle, J. Resilience Tested, A Year and a Half of Ten Thousand Aftershocks; University of Canterbury: Christchurch, New Zealand, 2012.

82. Hussein, E.; Daoud, S.; Alrabaiah, H.; Badawi, R. Exploring undergraduate students' attitudes towards emergency online learning during COVID-19: A case from the UAE. Child. Youth Serv. Rev. 2020, 119, 105699. [CrossRef]

83. D'Orsie, S.M.; Day, K. Ten Tips for teaching a web course. Tech. Dir. 2006, 65, 18.

84. Shah, H.J.; Attiq, S. Impact of technology quality, perceived ease of use and perceived usefulness in the formation of consumer's satisfaction in the context of e-learning. J. Appl. Learn. Tech. 2016, 9, 124-140.

85. Iqbal, S.A.; Tayyab, N. Letter to Editor. J. Loss Trauma 2021, 26, 97-100. [CrossRef]

86. Ullah, A.; Ashraf, M.; Ashraf, S.; Ahmed, S. Challenges of online learning during the COVID-19 pandemic encountered by students in Pakistan. J. Pedagog. Socio. Psyc. 2021, 3, 36-44. [CrossRef]

87. Dobbs, R.R.; Waid-Lindberg, C.A.; del Carmen, A. Students' perceptions of online courses: The effect of online course experience. Q. Rev. Distance Educ. 2017, 18, 93-109.

88. Lieberman, M. Going online When Disaster Strikes. Available online: https://www.insidehighered.com/digital-learning/article/ 2017/09/06/universities-proactively-prepare-online-transition-amid (accessed on 15 June 2021).

89. Pierre-Pierre, G. HAITI: New University to Avoid Quake Devastation. Available online: https:/ / www.universityworldnews. com/post.php?story=20110122090430535 (accessed on 17 January 2021).

90. Murphy, M.P.A. COVID-19 and emergency eLearning: Consequences of the securitization of higher education for post-pandemic pedagogy. Contemp. Secur. Policy 2020, 41, 492-505. [CrossRef] 